\title{
Root Substrate pH, Electrical Conductivity, and Macroelement Concentration of Sphagnum Peat-based Substrates Amended with Parboiled Fresh Rice Hulls or Perlite
}

\author{
Mary M. Gachukia ${ }^{1}$ and Michael R. Evans ${ }^{2,3}$
}

AdDitional INDEX wORDs. EC, growing media, PBH, soil chemistry

\begin{abstract}
SumMary. Substrates were formulated by blending parboiled fresh rice (Oryza sativa) hulls $(\mathrm{PBH})$ or perlite with sphagnum peat (peat) to produce root substrates (substrates) that contained $20 \%, 30 \%, 40 \%, 50 \%$, or $60 \%$ (by volume) $\mathrm{PBH}$ or perlite with the remainder being peat. After 0 (initial mixing), 4, or 8 weeks in a greenhouse environment, samples were taken and $\mathrm{pH}$, electrical conductivity (EC), nitrate $\left(\mathrm{NO}_{3}{ }^{-}\right)$, ammonium $\left(\mathrm{NH}_{4}^{+}\right)$, phosphorus $(\mathrm{P})$, and potassium $(\mathrm{K})$ were determined. As the amount of $\mathrm{PBH}$ or perlite in the substrate was increased, the $\mathrm{pH}$ increased. After 0 and 8 weeks, the $\mathrm{pH}$ of substrates containing up to $30 \% \mathrm{PBH}$ or perlite had a similar $\mathrm{pH}$. However, the rate of $\mathrm{pH}$ increase at these sampling times was higher than that of perlite so that substrates containing $40 \%$ or more $\mathrm{PBH}$ had a higher $\mathrm{pH}$ than equivalent perlite-containing substrates. At the week 4 sampling period, all substrates containing $\mathrm{PBH}$ had a higher $\mathrm{pH}$ than equivalent perlite-containing substrates. For all sampling times, the difference in $\mathrm{pH}$ between equivalent $\mathrm{PBH}$ and perlite-containing substrates was not high enough to be of practical significance. For all sampling times, EC increased as the amount of perlite was increased. Depending upon sampling time, the EC decreased or remained unchanged as the amount of PBH was increased. For all sampling times and substrates, EC was within acceptable ranges for unused substrates. Substrates containing $\mathrm{PBH}$ had higher $\mathrm{NO}_{3}{ }^{-}$levels than equivalent perlite-containing substrates. The $\mathrm{NH}_{4}{ }^{+}$level of the substrates decreased as the amount of $\mathrm{PBH}$ or perlite was increased. The levels of $\mathrm{NO}_{3}{ }^{-}$and $\mathrm{NH}_{4}{ }^{+}$were within acceptable ranges for unused substrates. Substrate $P$ and $K$ increased as the amount of $P B H$ in the substrate was increased, but the concentration of $P$ and $K$ remained unchanged or decreased as the amount of perlite was increased. None of the differences between equivalent $\mathrm{PBH}$ and perlite-containing substrates was high enough to be problematic with respect to crop production and all of the chemical parameters were within acceptable ranges for unused root substrates.
\end{abstract}

$\mathrm{R}$ oot substrates (substrates) are commonly used in the production of containerized greenhouse and nursery crops (Bunt 1988; Nelson, 2003). Substrates are formulated from various inorganic and organic components to provide suitable physical and chemical properties as required by the specific crop and growing conditions (Bunt, 1988). One important physical property of substrates is air-filled pore space (Bunt, 1988). Air-filled pores allow for drainage and gas exchange between the root environment and the outside atmosphere. Various materials have been used to provide for air-filled pore space in substrates,

\footnotetext{
Department of Horticulture, University of Arkansas, 315 Plant Science Bldg., Fayetteville, AR 72701

${ }^{1}$ Graduate Student.

${ }^{2}$ Associate Professor.

${ }^{3}$ Corresponding author. E-mail: mrevans@uark.edu.
}

with one of the most common being perlite (Bunt, 1988).

Perlite is an inorganic expanded aluminosilicate of volcanic origin (Nelson, 2003), and it is produced by mining the ore, grinding the crude ore to the desired particle size, and heating it to temperatures of up to $982{ }^{\circ} \mathrm{C}$. Heating causes the ore to expand from four to 20 times its original volume, resulting in a lightweight white porous particle (Hanan, 1998). Because of the costs associated with mining, transportation, and heating, perlite has been a relatively expensive substrate component. In addition to its cost, in its dry state, perlite produces a siliceous dust that is an eye and lung irritant. Substrate components that are lower in cost, do not have the dust issues associated with perlite, and could provide for air-filled pore space in the substrate would be beneficial to the nursery and greenhouse crop industries.

Some potential alternative components to perlite (i.e., shredded rubber and ground bovine bone) had undesirable chemical properties (Evans, 2004; Evans and Harkess, 1997; Handrek, 1996) such as high $\mathrm{pH}$, high $\mathrm{NH}_{4}{ }^{+}$, high electrical conductivity (EC), or phytotoxic levels of one or more mineral nutrients. Other materials evaluated as potential alternatives to perlite were too expensive or had unacceptably high bulk densities (i.e., calcined clay aggregates, gravel) that resulted in unacceptably high shipping costs for most horticultural uses.

Parboiled fresh rice hulls $(\mathrm{PBH})$ are a milling coproduct of the rice industry and comprise $\approx 20 \%$ of the rice grain at harvest (Kamath and Proctor, 1998). $\mathrm{PBH}$ are obtained as a result of a steaming process and are therefore sterile and free of viable weed seed when initially produced. Evans and Gachukia (2004) demonstrated that PBH could be successfully used as an alternative to perlite in the root substrate for the production of several ornamental species. Evans and Gachukia (2007) also reported how PBH affected the physical properties of sphagnum peat-based substrates compared with perlite. However, the effects that $\mathrm{PBH}$ has on the chemical properties of sphagnum peat-based substrates compared with perlite have not been reported.

The objectives of this study were to determine the effect of increasing concentrations of $\mathrm{PBH}$ and perlite on

\begin{tabular}{llll}
\hline $\begin{array}{l}\text { Units } \\
\text { To convert U.S. to SI, } \\
\text { multiply by }\end{array}$ & U.S. unit & SI unit & $\begin{array}{l}\text { To convert SI to U.S., } \\
\text { multiply by }\end{array}$ \\
\hline 29.5735 & $\mathrm{fl} \mathrm{oz}$ & $\mathrm{mL}$ & 0.0338 \\
2.54 & inch $(\mathrm{es})$ & $\mathrm{cm}$ & 0.3937 \\
1 & $\mathrm{mmho} / \mathrm{cm}$ & $\mathrm{dS} \cdot \mathrm{m}^{-1}$ & 1 \\
1 & $\mathrm{ppm}$ & $\mathrm{mg} \cdot \mathrm{kg}^{-1}$ & 1 \\
1 & $\mathrm{ppm}$ & $\mathrm{mg} \cdot \mathrm{L}^{-1}$ & 1 \\
$\left({ }^{\circ} \mathrm{F}-32\right) \div 1.8$ & ${ }^{\circ} \mathrm{F}$ & ${ }^{\circ} \mathrm{C}$ & $\left(1.8 \times{ }^{\circ} \mathrm{C}\right)+32$
\end{tabular}


the $\mathrm{pH}, \mathrm{EC}, \mathrm{NO}_{3}^{-}, \mathrm{NH}_{4}{ }^{+}, \mathrm{P}$, and $\mathrm{K}$ of a sphagnum peat-based substrate, to determine if these chemical properties were affected differently by increasing amounts of $\mathrm{PBH}$ and perlite, and to determine if these chemical properties were within acceptable ranges for use in substrates.

\section{Materials and methods}

$\mathrm{PBH}$ were obtained from Riceland Foods (Stuttgart, AR). Perlite and sphagnum peat (peat) were obtained from Sun Gro Horticulture (Bellevue, WA). Perlite and PBH had an initial $\mathrm{pH}$ of 7.5 and 6.5 in a deionized water saturated extract, respectively. Peat had an initial $\mathrm{pH}$ of 3.5. However, calcitic lime was added to the peat 7 days before formulation of the substrates to adjust the $\mathrm{pH}$ to $\approx 5.0$.

Ten substrates were formulated by blending $\mathrm{PBH}$ or perlite in a rotary mixer for $1 \mathrm{~min}$ at $50 \mathrm{rpm}$ to produce root substrates that contained $20 \%$, $30 \%, 40 \%, 50 \%$, or $60 \%$ (by volume) $\mathrm{PBH}$ or perlite with the remainder being peat. The substrates were moistened to $60 \%$ (by weight) during mixing with deionized water. Substrates were then placed into $10-\mathrm{cm}^{-}$ diameter $(600 \mathrm{~mL})$ plastic containers without compaction. Containers were transferred to a glass-glazed greenhouse. Air temperatures were maintained between $20^{\circ} \mathrm{C}$ and $25^{\circ} \mathrm{C}$ under ambient light levels (350$525 \mu \mathrm{mol} \cdot \mathrm{s}^{-1} \cdot \mathrm{m}^{-2}$ at $1200 \mathrm{HR}$ ) and naturally occurring photoperiods from April through September in Fayetteville, AR. The substrates in each container were maintained moist, but without leaching, by applying $60 \mathrm{~mL}$ of deionized water to the surface of the substrate by hand on alternate days.
Substrate samples were taken after 0 (after initial mixing), 4 , and 8 weeks in the greenhouse environment. These times were selected to determine initial parameters, parameters in the middle of a typical annual bedding plant crop cycle, and parameters near the end of such a greenhouse crop cycle.

Substrate EC, $\mathrm{pH}$, and nutrient status were determined using the saturated media extract method as outlined by the North Central Regional Committee for Soil and Plant Analysis (Warncke, 1988). EC was determined using an EC meter (model 441; Corning, Corning, NY), and the $\mathrm{pH}$ was determined using a $\mathrm{pH}$ meter (model AB 15; Fisher Scientific, Pittsburgh). $\mathrm{NO}_{3}-\mathrm{N}$ concentration was determined using the copperized cadmium reduction procedure (Keeney and Nelson, 1982) and $\mathrm{NH}_{4}-\mathrm{N}$ was determined by the nitroprusside-salicylate procedure (Wall, et al., 1975). The concentration of $\mathrm{P}$ and $\mathrm{K}$ was determined using the filtered extract for simultaneous inductively coupled plasma emission spectrometry (Jones, 1977; Munter and Grande, 1981).

Each container served as a replication. The experimental design was a completely randomized design with nine independent replications per substrate and sampling time. An analysis of variance was conducted to determine if substrate component, component percentage, or sampling time in greenhouse environment affected the chemical properties and whether significant interactions occurred among these variables. For each sampling time, substrate chemical properties were regressed against the percentage of $\mathrm{PBH}$ or perlite to determine how the amount of each affected each chemical property tested.

\section{Results and discussion}

For all of the parameters measured, component, percentage of the component and sampling time were significant (Table 1). Additionally, for all parameters except phosphorus, all interactions among the variables were significant. When substrates were initially blended (after 0 weeks), substrates containing $20 \%$ perlite and $20 \% \mathrm{PBH}$ had a similar $\mathrm{pH}$ of $\approx 5.0$ (Fig. 1A). As the amount of perlite or $\mathrm{PBH}$ was increased, the $\mathrm{pH}$ of the substrates increased. However, the $\mathrm{pH}$ of substrates containing $\mathrm{PBH}$ increased at a higher rate than those containing perlite. After 4 weeks in the greenhouse environment, increasing amounts of perlite or $\mathrm{PBH}$ resulted in an increasing $\mathrm{pH}$ (Fig. 1B). The rate of $\mathrm{pH}$ increase was similar for perlite and $\mathrm{PBH}$. For all concentrations of perlite or $\mathrm{PBH}$ after 4 weeks, $\mathrm{PBH}$-containing substrate had a higher $\mathrm{pH}$ than substrates containing an equivalent amount of perlite. After 8 weeks in the greenhouse environment, the substrate containing $20 \%$ perlite had a higher $\mathrm{pH}$ than the substrate containing $20 \% \mathrm{PBH}$ (Fig. 1C). Substrates containing 30\% of perlite or $\mathrm{PBH}$ had a similar $\mathrm{pH}$. The $\mathrm{pH}$ of perlite- and $\mathrm{PBH}$-containing substrates increased as the amount of perlite or $\mathrm{PBH}$ increased. However, the $\mathrm{pH}$ of substrates containing $\mathrm{PBH}$ increased at a higher rate than perlite. This resulted in substrates containing more than $30 \% \mathrm{PBH}$ having a higher $\mathrm{pH}$ than equivalent perlite-containing substrates.

Increasing $\mathrm{PBH}$ or perlite resulted in an increase in substrate $\mathrm{pH}$. This may have been a function

Table 1. Main effect and interactions for $\mathrm{pH}, \mathrm{EC}$, and macroelement concentration of sphagnum peat-based substrates amended with parboiled fresh rice hulls or perlite.

\begin{tabular}{|c|c|c|c|c|c|c|c|}
\hline $\begin{array}{l}\text { Chemical } \\
\text { property }^{z}\end{array}$ & Component $^{\mathbf{y}}$ & $\%$ Component $^{\mathrm{x}}$ & Time $^{w}$ & $\begin{array}{l}\text { Component } \times \\
\% \text { Component }\end{array}$ & $\begin{array}{l}\text { Component } \times \\
\text { Time }\end{array}$ & $\begin{array}{c}\text { \% Component } \times \\
\text { Time }\end{array}$ & $\begin{array}{c}\text { Component } \times \% \\
\text { Component } \times \text { Time }\end{array}$ \\
\hline $\mathrm{pH}$ & $\star \star *$ & $\star \star \star$ & $\star * *$ & * & ** & $\star * \star$ & * \\
\hline $\mathrm{EC}$ & $* * *$ & $\star * *$ & $* * *$ & *** & $* *$ & $\star * *$ & $\star * *$ \\
\hline $\mathrm{NO}_{3}{ }^{-}$ & $\star * *$ & $\star * *$ & $\star * *$ & *** & $* * *$ & $* * *$ & $\star * *$ \\
\hline $\mathrm{NH}_{4}{ }^{+}$ & $\star * *$ & $\star * *$ & $\star * *$ & $* *$ & $\star *$ & $\star * *$ & $* * *$ \\
\hline $\mathrm{P}$ & $\star \star *$ & $\star * *$ & * & $\star * *$ & NS & NS & NS \\
\hline $\mathrm{K}$ & $\star \star \star$ & $\star \star \star$ & $\star \star \star$ & $\star * *$ & $\star \star \star$ & $\star \star \star$ & $\star \star \star$ \\
\hline
\end{tabular}

${ }^{\mathrm{z} N i t r a t e}\left(\mathrm{NO}_{3}^{-}\right)$, ammonium $\left(\mathrm{NH}_{4}^{+}\right)$phosphorus $(\mathrm{P})$, and potassium $(\mathrm{K})$

${ }^{\mathrm{y}} \mathrm{Components}=$ perlite or parboiled fresh rice hulls.

x\% Component $=$ percentage of perlite or parboiled fresh rice hulls occurring in the peat-based substrates $(20 \%, 30 \%, 40 \% 50 \%$, or $60 \%$ by volume $)$.

"Time = substrate sampling time $(0,4$, and 8 weeks in a greenhouse environment).

NS, ${ }^{*},{ }^{* *},{ }^{\star \star *}$ Nonsignificant or significant at $P=0.05,0.01$, and 0.001 , respectively. 
of reducing the overall amount of peat in the substrate, which was the more acidic component of the substrate. However, substrates containing $\mathrm{PBH}$ always had a higher $\mathrm{pH}$ or the $\mathrm{pH}$ increased at a higher rate than substrates containing perlite. This may have been a function of the silica content of $\mathrm{PBH}$, which contained $\approx 20 \%$ silica (Kamath and Proctor, 1998). Silicates act as bases and would therefore have increased the substrate $\mathrm{pH}$. It is important, however, to note that depending upon the sampling time, the increase in $\mathrm{pH}$ with increasing amounts of $\mathrm{PBH}$ or perlite was only 0.5 units at the maximum. Furthermore, the difference in $\mathrm{pH}$ between equivalent $\mathrm{PBH}$ - and perlite-containing substrates was only 0.2 units at the maximum. This difference in $\mathrm{pH}$ between $\mathrm{PBH}$ - and perlite-containing substrates would have no practical significance in commercial production situations.

After 0 weeks, substrates containing $20 \%$ perlite or $20 \% \mathrm{PBH}$ had a similar EC. However, as the amount of perlite was increased, the EC of the substrate increased, while the EC decreased as the amount of $\mathrm{PBH}$ was increased (Fig. 2A). After 4 weeks, the substrate containing $20 \%$ $\mathrm{PBH}$ had a higher EC than the substrate containing 20\% perlite (Fig. 2B). However, as the amount of perlite was increased, the EC increased, while as the amount of $\mathrm{PBH}$ was increased, the EC decreased. After 8 weeks, at all concentrations of perlite- or
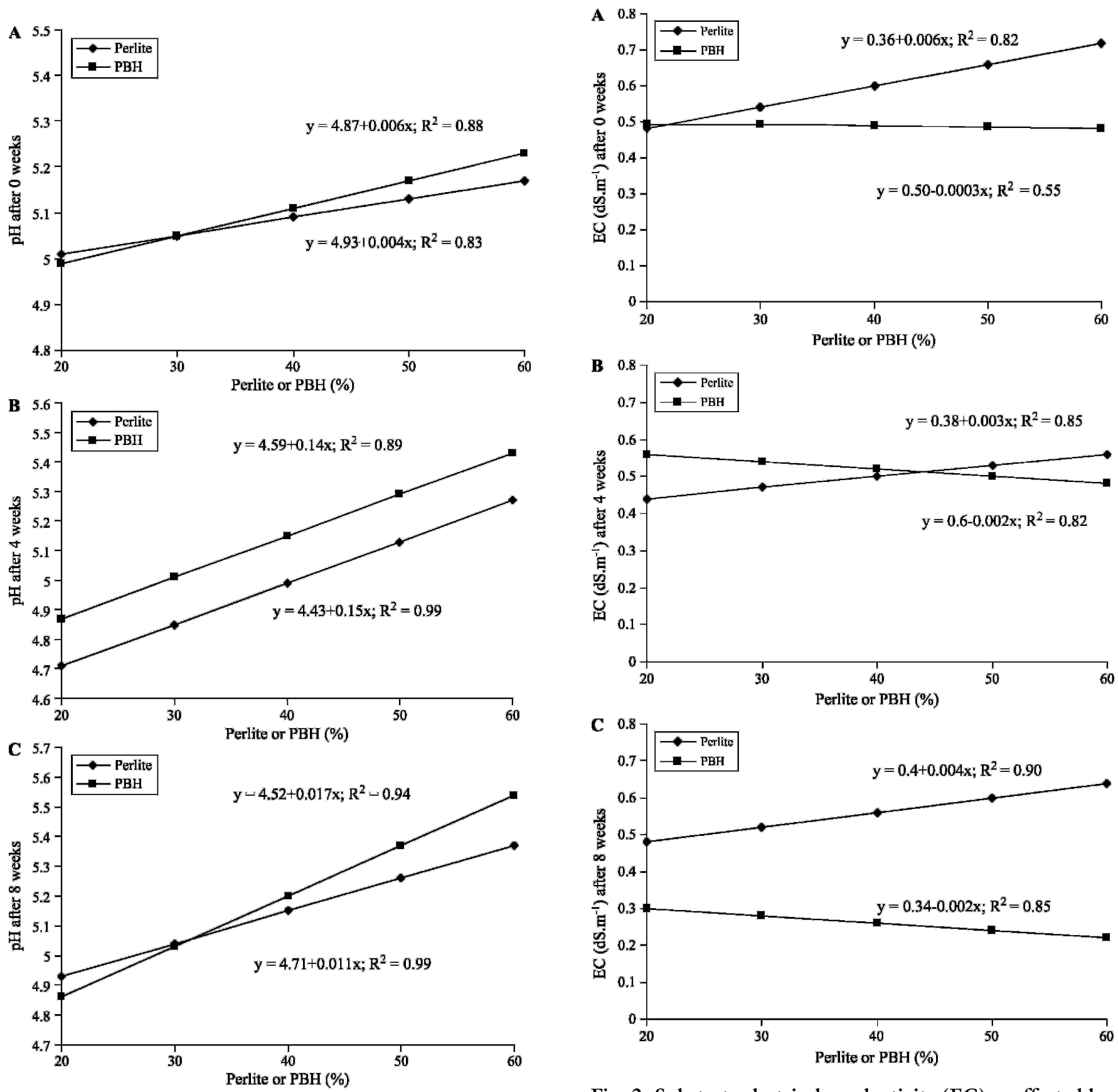

Fig. 1. Substrate $\mathrm{pH}$ as affected by parboiled fresh rice hulls $(\mathrm{PBH})$ and perlite concentration after 0,4 , and 8 weeks.

Fig. 2. Substrate electrical conductivity (EC) as affected by parboiled fresh rice hulls $(\mathrm{PBH})$ and perlite concentration after 0,4 , and 8 weeks $\left(1 \mathrm{dS} \cdot \mathrm{m}^{-1}=1 \mathrm{mmho} / \mathrm{cm}\right)$. 
$\mathrm{PBH} /$ perlite-containing substrates had a higher EC than $\mathrm{PBH}$-containing substrates (Fig. 2C). As the amount of perlite was increased, the EC increased, while as the amount of $\mathrm{PBH}$ was increased, the EC decreased.

Whereas the perlite was produced from a raw mineral that was heated and expanded, $\mathrm{PBH}$ had essentially been washed in hot water during the parboiling process. Therefore, mineral residue of the perlite may have resulted in a higher EC for perlite-containing substrates than for $\mathrm{PBH}$-containing substrates. However, the maximum difference between the EC of an equivalent $\mathrm{PBH}-$ and perlite-containing substrate was $\approx 0.4 \mathrm{dS} \cdot \mathrm{m}^{-1}$, and all substrates had EC levels within acceptable ranges for greenhouse crops production.

After 0 weeks, substrates containing $20 \%$ perlite or $\mathrm{PBH}$ had similar $\mathrm{NO}_{3}{ }^{-}$concentrations (Fig. 3A), but as the amount of $\mathrm{PBH}$ increased, the $\mathrm{NO}_{3}^{-}$concentration increased. The $\mathrm{NO}_{3}{ }^{-}$concentration of perlite- containing substrates decreased with increasing amounts of perlite. After 4 and 8 weeks (Fig. 3, B and C), the concentration of $\mathrm{PBH}$ did not significantly affect the $\mathrm{NO}_{3}{ }^{-}$concentration of the substrate, but as perlite was increased to higher than $30 \%$, the $\mathrm{NO}_{3}{ }^{-}$concentration declined.

When substrates were initially blended, substrates containing 20\% $\mathrm{PBH}$ had a higher $\mathrm{NH}_{4}{ }^{+}$concentration than equivalent perlite-containing substrates (Fig. 4A). As the amount of $\mathrm{PBH}$ or perlite was
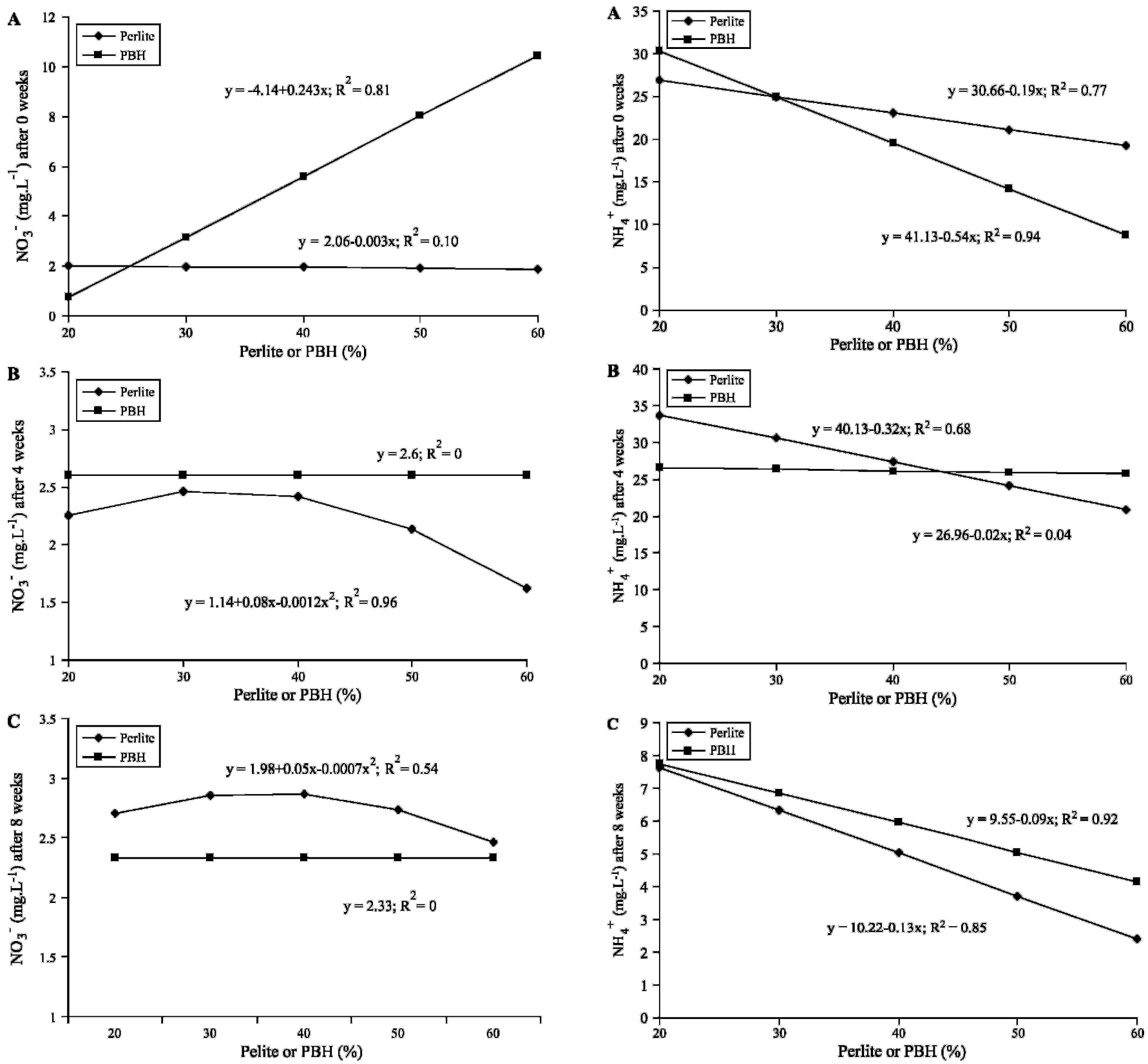

Fig. 3. Substrate nitrate $\left(\mathrm{NO}_{3}{ }^{-}\right)$concentration as affected by parboiled fresh rice hulls $(\mathrm{PBH})$ and perlite concentration after 0,4 , and 8 weeks $\left(1 \mathrm{mg} \cdot \mathrm{L}^{-1}=1 \mathrm{ppm}\right)$.

Fig. 4. Substrate ammonium $\left(\mathrm{NH}_{4}{ }^{+}\right)$concentration as affected by parboiled fresh rice hulls $(\mathrm{PBH})$ and perlite concentration after 0,4 , and 8 weeks $\left(1 \mathrm{mg} \cdot \mathrm{L}^{-1}=1 \mathrm{ppm}\right)$. 
increased, the $\mathrm{NH}_{4}{ }^{+}$concentration decreased, but at a higher rate for $\mathrm{PBH}$-containing substrates. After 4 weeks in the greenhouse environment, $\mathrm{NH}_{4}{ }^{+}$concentration decreased as the amount of perlite or $\mathrm{PBH}$ was increased, but at a higher rate in perlite-containing substrates (Fig. 4B). After 8 weeks in the greenhouse environment, $\mathrm{NH}_{4}{ }^{+}$concentration was similar for substrates containing $20 \%$ perlite or $\mathrm{PBH}$ and $\mathrm{NH}_{4}{ }^{+}$concentration decreased for perlite- and $\mathrm{PBH}-$ containing substrates as the amount of either was increased. At all concentrations above $20 \%, \mathrm{PBH}$-containing substrates had higher $\mathrm{NH}_{4}{ }^{+}$concentrations than equivalent perlite-containing substrates (Fig. 4C).

According to Cadell (1988), fresh rice hulls contained 3200 $\mathrm{mg} \cdot \mathrm{kg}^{-1}$ total nitrogen. Rice hulls also contain small amounts of bran and rice grains, both of which contain proteins that would serve as a potential source of nitrogen. After parboil- ing, decomposition of the bran and rice grains by microorganisms could have resulted in a release of nitrogen that could have then been mineralized. Therefore, $\mathrm{PBH}$ could have contributed $\mathrm{NO}_{3}{ }^{-}$to the substrate and resulted in the $\mathrm{PBH}$-containing substrates having higher $\mathrm{NO}_{3}^{-}$than equivalent perlite-containing substrates. However, $\mathrm{NH}_{4}^{+}$remained constant or decreased with increasing amounts of $\mathrm{PBH}$ or perlite. Therefore, $\mathrm{PBH}$ and perlite were not the
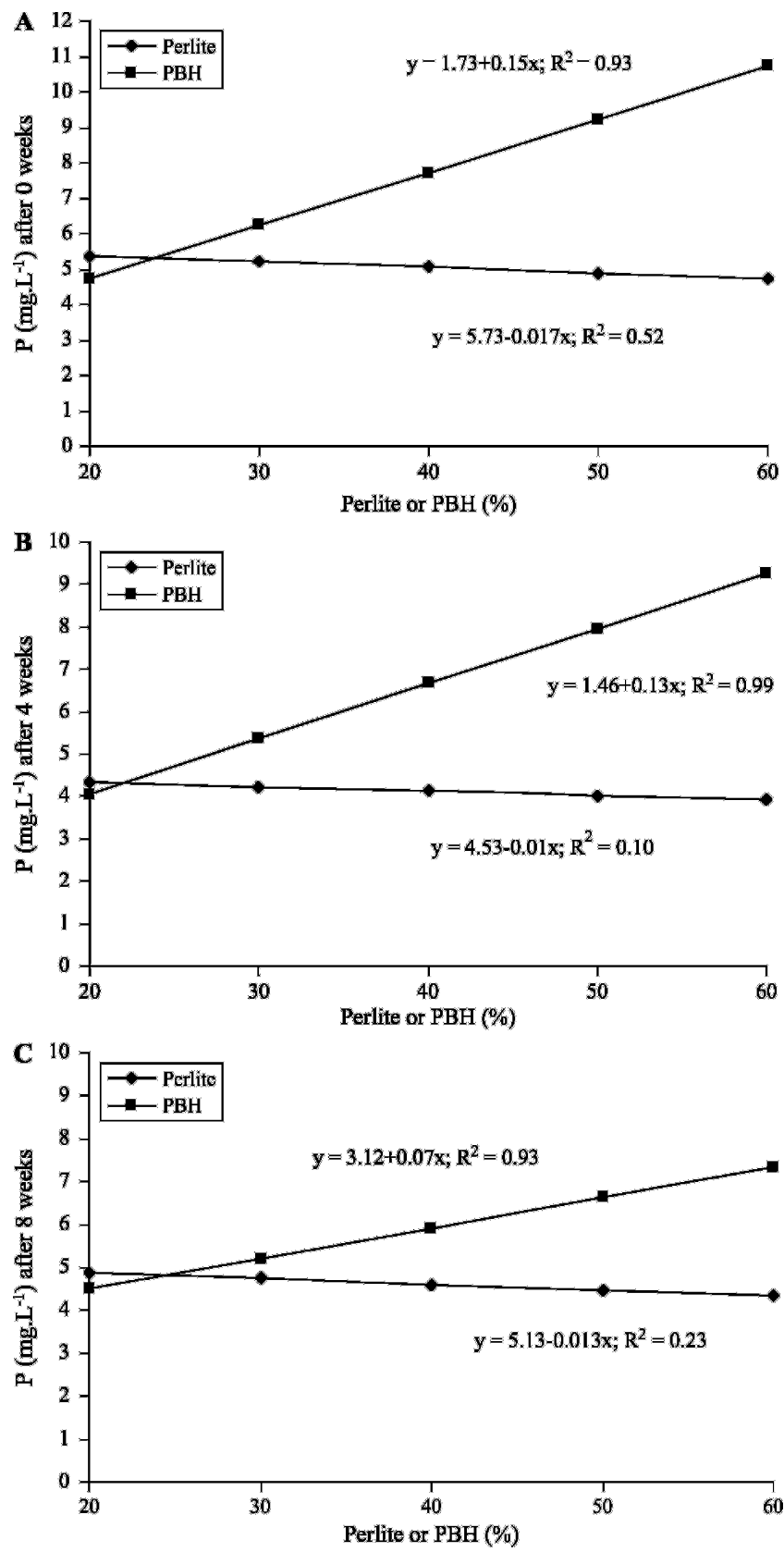

Fig. 5. Substrate phosphorus $(\mathrm{P})$ concentration as affected by parboiled fresh rice hulls $(\mathrm{PBH})$ and perlite concentration after 0,4 , and 8 weeks $\left(1 \mathrm{mg} \cdot \mathrm{L}^{-1}=1 \mathrm{ppm}\right)$.
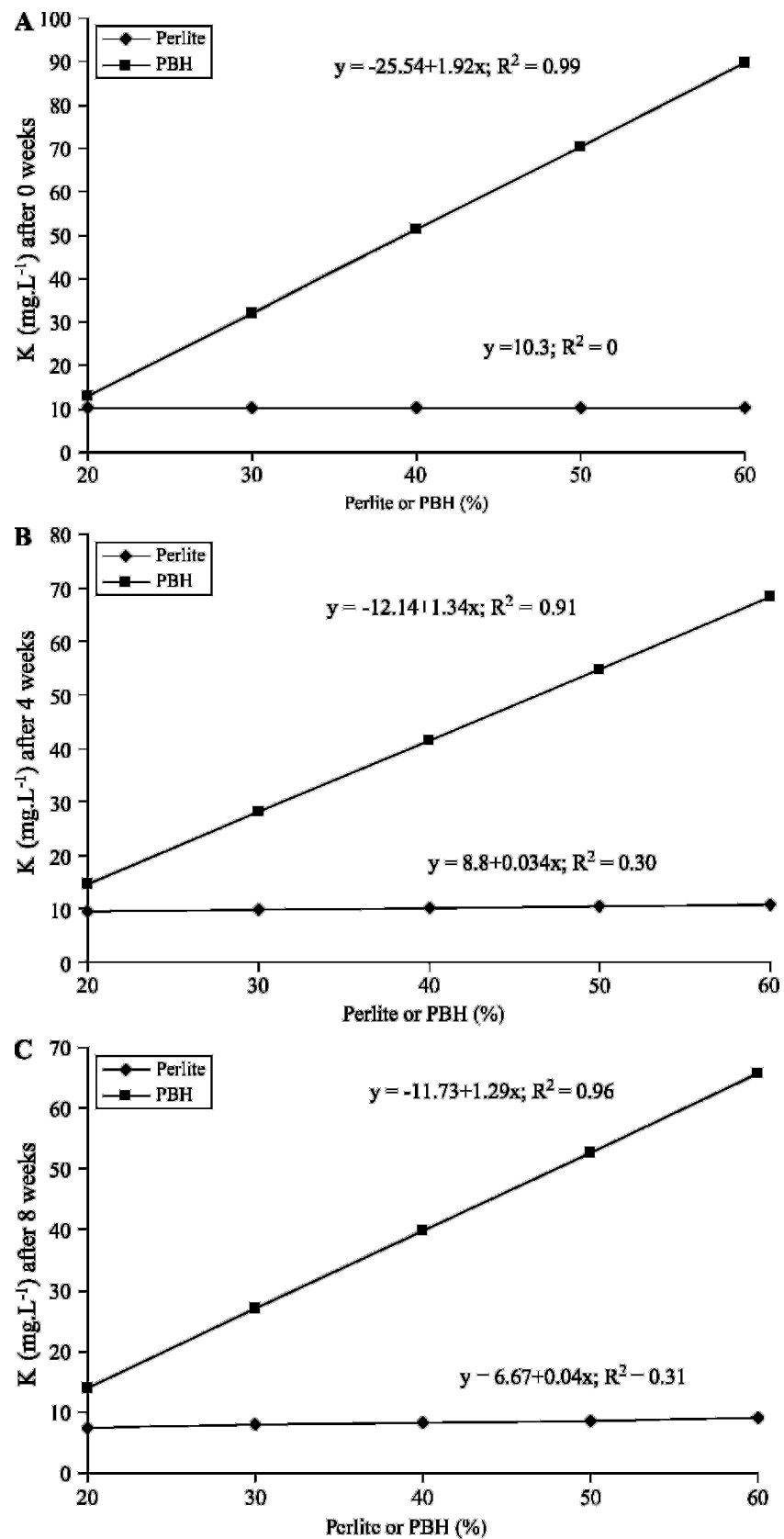

Fig. 6. Substrate potassium (K) concentration as affected by parboiled fresh rice hulls $(\mathrm{PBH})$ and perlite concentration after 0,4 , and 8 weeks $\left(1 \mathrm{mg} \cdot \mathrm{L}^{-1}=1 \mathrm{ppm}\right)$. 
source of $\mathrm{NH}_{4}{ }^{+}$in the substrates. As would have been expected, $\mathrm{NH}_{4}{ }^{+}$ decreased over time in $\mathrm{PBH}-$ and perlite-containing substrates and was within ranges acceptable for most crop production situations.

For all sampling times, substrates containing $20 \%$ perlite or $\mathrm{PBH}$ had similar $\mathrm{P}$ concentrations (Fig. 5, AC). As the amount of $\mathrm{PBH}$ in the substrate was increased, the $\mathrm{P}$ concentration increased. However, as the amount of perlite in the substrate was increased, the P concentration decreased.

After 0 weeks, the substrate $\mathrm{K}$ was similar for substrates containing $20 \%$ perlite or $\mathrm{PBH}$ (Fig. 6A). However, as the amount of $\mathrm{PBH}$ was increased, the $\mathrm{K}$ concentration increased. As the amount of perlite was increased, the $\mathrm{K}$ concentration remained unchanged. After 4 and 8 weeks in the greenhouse environment, all substrates containing $\mathrm{PBH}$ had a higher concentration of $\mathrm{K}$ than equivalent perlite-containing substrates and as the amount of $\mathrm{PBH}$ was increased, the $\mathrm{K}$ concentration increased at a higher rate than for perlite-containing substrates (Fig. 6, $\mathrm{B}$ and $\mathrm{C})$.

Fresh rice hulls were reported to contain $34 \mathrm{mg} \cdot \mathrm{kg}^{-1} \mathrm{P}$ and 5010 $\mathrm{mg} \cdot \mathrm{kg}^{-1} \mathrm{~K}$ (Cadell, 1988), whereas perlite was composed of $\approx 85 \%$ silicon dioxide $\left(\mathrm{SiO}_{2}\right)$ and aluminum oxide $\left(\mathrm{Al}_{2} \mathrm{O}_{3}\right)$, with only trace concentrations of oxides of iron, titanium, magnesium, calcium, sodium, manganese, and $\mathrm{K}$. The increase in $\mathrm{P}$ and $\mathrm{K}$ as the amount of $\mathrm{PBH}$ was increased in the substrate could be attributed to the $\mathrm{P}$ and $\mathrm{K}$ released from the $\mathrm{PBH}$ incorporated into the substrate. Although PBH-containing substrates generally had higher $\mathrm{P}$ and $\mathrm{K}$ concentrations than perlitecontaining substrate, for all sampling times and concentrations of $\mathrm{PBH}$, the $\mathrm{P}$ and $\mathrm{K}$ concentrations were within acceptable levels for unused root substrate.

\section{Conclusion}

For all amounts of $\mathrm{PBH}$ and perlite used and for all time periods sampled, the $\mathrm{PBH}$-containing substrates had similar $\mathrm{pH}, \mathrm{EC}, \mathrm{NO}_{3}^{-}$, $\mathrm{NH}_{4}{ }^{+}, \mathrm{P}$, and $\mathrm{K}$ concentrations as equivalent perlite-containing substrates or were within commonly recommended levels (Bunt, 1988; Nelson, 2003; Peterson et al., 1989). Therefore, the effects of $\mathrm{PBH}$ on the $\mathrm{pH}, \mathrm{EC}, \mathrm{NO}_{3}{ }^{-}, \mathrm{NH}_{4}{ }^{+}$, $\mathrm{P}$, and $\mathrm{K}$ concentrations of peat-based root substrates would not present cultural problems or require significant production changes if used in root substrates as an alternative to perlite for providing for drainage and air-filled pore space.

\section{Literature cited}

Bunt, A.C. 1988. Media and mixes for container grown plants. Unwin Hyman, London.

Cadell, M.L. 1988. Rice hull composting in Australia. Biocycle 29(6):49.

Evans, M.R. 2004. Ground bovine bone as a perlite alternative in horticultural substrates. HortTechnolgy 14:171-175.

Evans, M.R. and M. Gachukia. 2004. Fresh parboiled rice hulls serve as an alternative to perlite in greenhouse crop substrates. HortScience 39:232-235.

Evans, M.R. and M.M. Gachukia. 2007. Physical properties of sphagnum peatbased root substrates amended with perlite or parboiled fresh rice hulls. HortTechnology 17:312-315.

Evans, M.R. and R.L. Harkess. 1997. Growth of Pelargonium $\times$ hortorum and Eurphorbia pulcherrima in rubber-con- taining substrates. HortScience 32:874877.

Hanan, J.J. 1998. Greenhouse-advanced technology for protected horticulture. CRC Press, Boca Raton, FL.

Handrek, K.A. 1996. Zinc toxicity from tire rubber in soilless potting media. Commun. Soil Sci. Plant Anal. 27:26152623.

Jones, J.B., Jr. 1977. Elemental analysis of soil extracts and plant tissue ash by plasma emission spectroscopy. Commun. Soil Sci. Plant Anal. 8:345-365.

Kamath, S.R. and A. Proctor. 1998. Silica gel from rice hull ash: Preparation and characterization. Cereal Chem. 75(4): 484-487.

Keeney, D.R. and D.W. Nelson. 1982. Nitrogen-inorganic forms, p. 643-698. In: A.L. Page (ed.). Methods of soil analysis, Part 2. 2nd ed. Amer. Soc. Agron., Madison, WI.

Munter, R.C. and R.A. Grande. 1981. Plant tissue and soil extract analysis by ICP-atomic emission spectrometry, p. 653-672. In: R.M. Barnes (ed.). Developments in atomic plasma spectrochemical analysis. Heyden and Sons, London.

Nelson, P.V. 2003. Greenhouse operation and management, 5th ed. Prentice Hall, Upper Saddle River, NJ.

Peterson, J.C., L.L. Kramer, and J. O'Bryan. 1989. Just what is in my soil, anyway. Interior Landscape Ind. 6(8):4850 .

Wall, L.L., C.W. Gehrke, T.E. Neuner, R.D. Cathey, and P.R. Rexroad. 1975. Total protein nitrogen: Evaluation and comparison of four different methods. J. Assn. Offic. Anal. Chem. 58:811-817.

Warncke, D. 1988. Recommended test procedures for greenhouse growth media, p. 34-37. In: W.C. Dahnke (ed.). Recommended chemical soil test procedures for the North Central Region. North Dakota Agr. Expt. Sta. Bul. 499. 